\title{
Upaya Meningkatkan Pembelajaran Tematik Melalui Strategi Pembelajaran Pairs- Checks Pada Siswa Kelas II Di SDN Jatigembol 2 Kecamatan Kedunggalar Kabupaten Ngawi Tahun Pelajaran 2017/2018
}

\author{
Masripatin \\ SDN Jatigembol 2 Kec. Kedunggalar, Kab. Ngawi
}

\begin{abstract}
Abstrak
Hambatan pembelajaran tematik sering dirasakan oleh siswa sekolah dasar, sehingga banyak siswa yang kurang menyenangi pelajaran pembelajaran tematik karena dianggap sulit. Kesulitan belajar yang banyak dirasakan siswa dalam pembelajaran tematik harus segera dicarikan solusi yang tepat agar tidak menjadi beban siswa dan mampu mengangkat prestasi hasil belajar siswa Kelas II khususnya, sehingga mampu meningkatkan hasil belajar yang tercermin dalam perolehan nilai evaluasi yang tinggi. Strategi Pembelajaran Pairs-Checks memberi tekanan pada latihan prestasi (achievement training). Anak-anak dibiasakan berikhtiar mencapai hasil kerja maksimal dan percaya diri akan kemampuannya. Dengan kata lain ia dibiasakan untuk bertanggung jawab sendiri. Orang tua dan guru harus dapat mendorong anak untuk menyelesaikan suatu pekerjaan atau tugas tertentu dengan frekuensi yang tinggi. Jika hasil pekerjaan tersebut dapat diselesaikan dengan baik dan sempurna, orang tua dan guru haruslah memberikan reirforcement untuk mendorong penyelesaian Strategi Pembelajaran Pairs-Checks berikutnya, begitu seterusnya, sampai anak mencapai prestasi yang optimal. Dalam kaitannya dengan hasil belajar sebagai salah satu produktivitas atau prestasi intelektual kehadiran bahan bacaan yang mengarah terhadap pembentukan prestasi sangat dibutuhkan, baik itu dalam bentuk cerita bergambar maupun cerita dalam majalah anak-anak, latihan (pembelajaran tematik) yang terdapat didalamnya secara tidak langsung akan mempengaruhi tingkat keberhasilan anak apalagi ditunjang dengan adanya buku-buku paket pelajaran dan buku latihan yang cukup banyak.

Strategi Pembelajaran Pairs-Checks berpengaruh terhadap hasil belajar siswa Kelas II Sekolah Dasar Negeri Jatigembol 2 Kecamatan Kedunggalar Kabupaten Ngawi. Semakin tinggi frekuensi Strategi Pembelajaran Pairs-Checks yang diberikan oleh guru dan orang tua, maka semakin kuat kemampuan Strategi Pembelajaran PairsChecks dapat dipraktekkan oleh siswa, sehingga akan meningkatkan hasil belajar siswa. Demikian juga dengan koleksi bahan bacaan juga berpengaruh terhadap hasil belajar siswa Kelas II dalam pembelajaran tematik. Semakin lengkap koleksi bahan bacaan pembelajaran tematik, maka semakin tinggi hasil belajar yang diperoleh siswa. Hal ini terbukti pada siklus I rata-rata nilai yang diperoleh 72,57 meningkat pada siklus II 85,71.

Strategi Pembelajaran Pairs-Checks dan koleksi bahan bacaan merupakan suatu rangkaian yang saling terkait dan mendukung sebagai upaya meningkatkan hasil belajar siswa Kelas II Sekolah Dasar Negeri Jatigembol 2 Kecamatan Kedunggalar Kabupaten Ngawi dalam pembelajaran tematik.
\end{abstract}

Kata Kunci: Tematik, Strategi Pembelajaran Pairs-Checks 


\section{PENDAHULUAN}

Dalam sejarah pendidikan Indonesia yang telah digelar selama ini, usaha-usaha untuk merilis kemajuan bukanlah berjalan tanpa kendala. Segala bentuk pembaharuan pendidikan telah dicoba, baik melalui pembaharuan kurikulum dari masa ke masa, maupun melalui pembaharuan di bidang strategi belajar mengajar dan penerapan kaidah-kaidah psikologi belajar baik yang klasik, konvensional sampai dengan konsep-konsep mutakhir yang kini dikembangluaskan. Keadaan seperti ini berakibat adanya tuntutan kepada para guru di sekolah untuk selalu seiring dengan kemajuan jaman dan metode yang tepat dalam pelaksanaan pengajaran. Guru haruslah mengikuti kemana laju segala bentuk pembaharuan pendidikan tersebut.

Pada umumnya metode maupun strategi pembelajaran yang dikembangkan oleh guru dalam kegiatan belajar mengajar adalah metode maupun strategi pembelajaran yang memfokuskan diri pada upaya pemindahan pengetahuan ke dalam kepala siswa tanpa memperhatikan bahwa ketika siswa memasuki kelas, siswa mempunyai bekal kemampuan dan pengetahuan yang tidak sama. Siswa hanya ditempatkan sebagai objek, sehingga siswa menjadi pasif dan tenggelam dalam kondisi belajar yang kurang merangsang aktivitas belajar yang optimal.

Dalam proses belajar mengajar setiap guru mempunyai teknik maupun cara berpikir yang berbeda-beda dalam menyampaikan materi pelajaran yang diberikan kepada siswanya. Dengan menggunakan berbagai metode atau cara dalam menyampaikan materinya, ada yang menggunakan media visual yang tidak diproyeksikan, ada yang menggunakan media visual yang diproyeksikan dan ada pula yang menggunakan media audio. Penyampaian materi yang selama ini digunakan oleh guru adalah dengan cara konvensional ceramah yang membuat kebanyakan murid merasa jenuh atau bosan dengan pendekatan tersebut. Berawal dari perbedaan tersebut maka sering dijumpai keluhan dari para orang tua yang mempersoalkan cara belajar anaknya maupun media yang digunakan oleh siswa. Disamping itu, gurupun ada yang mengeluh banyak siswanya yang pasif jika media belajar yang digunakan tidak sesuai dengan keinginan.

Salah satu tindakan guru yang utama adalah menyelenggarakan proses pembelajaran. Proses pembelajaran merupakan serangkaian kegiatan antara guru dengan siswa atas dasar hubungan timbal balik yang berlangsung dalam situasi edukatif untuk mencapai tujuan tertentu. Hubungan timbal balik antara guru dan siswa tersebut merupakan syarat utama dalam pelaksanaan proses pembelajaran. Interaksi dalam proses pembelajaran mengandung makna yang lebih luas dari pada sekedar hubungan antara guru dan siswa, sebab di dalamnya terkandung makna interaksi edukatif, yang tidak hanya berupa penyampaian pesan atau materi pelajaran, melainkan pemahaman nilai sikap dan karakter siswa.

Zainal Aqib (2014) menyatakan bahwa mengajar efektif adalah proses mengajar yang mampu menambah pengertian atau informasi baru bagi siswa. Agar tercapainya tujuan pembelajaran yang telah dirumuskan, seorang guru harus mengetahui berbagai metode. Dengan memiliki pengetahuan mengenai sifat berbagai metode maka seorang guru akan lebih mudah menetapkan metode paling sesuai dengan situasi dan kondisi. Penggunaan metode mengajar sangat 
bergantung pada tujuan pembelajaran. Masing-masing metode mempunyai kebaikan dan kelemahan karena itu perlu dipilih metode apa yang sesuai untuk pokok bahasan tertentu.

Hambatan belajar banyak terjadi pada anak-anak Indonesia, sekalipun penelitian seperti diatas belum pernah dilakukan. Dalam kamus psikologi belajar, mereka yang mengalami kesulitan belajar pada umumnya disebabkan oleh gangguan emosional yang muncul akibat pengalaman tak menyenangkan di masa lalu. Rasa bosan akibat pendidikan yang terlampau keras sehingga anak-anak tidak bersedia menyimak mata pelajaran yang diajarkan. Penolakan yang menyeluruh bukanlah satusatunya gejala kesulitan belajar. Ada hambatan yang spesifik, manakala otak menutup pintu hanya untuk mata pelajaran tertentu saja.

Hambatan pembelajaran tematik sering dirasakan oleh siswa sekolah dasar, sehingga banyak siswa yang kurang menyenangi pelajaran Pembelajaran tematik karena dianggap sulit. Kesulitan belajar yang banyak dirasakan siswa dalam pembelajaran tematik harus segera dicarikan solusi yang tepat agar tidak menjadi beban siswa dan mampu mengangkat prestasi hasil belajar siswa Kelas II khususnya, sehingga mampu meningkatkan hasil belajar yang tercermin dalam perolehan nilai evaluasi yang tinggi.

Strategi pembelajaran Pairs - Checks (Berpasangan dan Saling Memeriksa) adalah salah satu strategi pembelajaran berpasangan selain Think - Pairs - Share (TPS) dan Think - Pairs - Write (Berpikir Berpasangan - Menulis) pada model pembelajaran kooperatif. Strategi Pairs Checks ini dikembangkan oleh Spencer Kagan pada tahun 1993. Pada strategi ini siswa dilatih bekerja sama untuk mengerjakan soal-soal atau memecahkan masalah secara berpasangan. Model ini menerapkan pembelajaran berkelompok yang menuntut kemandirian dan kemampuan siswa dalam menyelesaikan persoalan yang diberikan. Banyak kelebihan maupun kelemahan dari metode Pair Check.

Kelebihannya

a. Dipandu belajar melalui bantuan rekan

b. Menciptakan saling kerjasama di antara siswa

c. Increases comprehension of concepts and/or processesMeningkatkan pemahaman konsep dan / atau proses

d. menmemenimelatih berkomunikasi

e. Melatih siswa untuk bersabar, yaitu dengan memberikan waktu bagi pasangannya untuk berpikir dan tidak langsung memberikan jawaban (menjawabkan) soal yang bukan tugasnya.

f. Melatih siswa memberikan dan menerima motivasi dari pasangannya secara tepat dan efektif.

g. Melatih siswa untuk bersikap terbuka terhadap kritik atau saran yang membangun dari pasangannya, atau dari pasangan lainnya dalam kelompoknya. Yaitu saat mereka saling mengecek hasil pekerjaan pasangan lain di kelompoknya.

h. Memberikan kesempatan pada siswa untuk membimbing orang lain (pasangannya).

i. Melatih siswa untuk bertanya atau meminta bantuan kepada orang lain (pasangannya) dengan cara yang baik (bukan langsung meminta jawaban, tapi lebih kepada cara-cara mengerjakan soal/menyelesaikan masalah).

j. Memberikan kesempatan kepada siswa untuk menawarkan bantuan atau bimbingan pada orang lain dengan cara yang baik. 
k. Memberikan kesempatan kepada siswa untuk belajar menjaga ketertiban kelas (menghindari keributan yang mengganggu suasana belajar)

Kekurangannya

a. memerlukan banyak waktu

b. memerlukan pemahaman yang tinggi terhadap konsep untuk menjadi pelatih.

c. Membutuhkan waktu yang lebih banyak.

d. Membutuhkan keterampilan siswa untuk menjadi pembimbing pasangannya, dan kenyataannya setiap partner pasangan bukanlah siswa dengan kemampuan belajar yang lebih baik. Jadi kadang-kadang fungsi pembimbingan tidak berjalan dengan baik

Adapun rumusan masalah dalam penelitian ini yaitu a. Apakah penyebab hambatan pembelajaran tematik pada siswa Kelas II Sekolah Dasar Negeri Jatigembol 2 Kecamatan Kedunggalar Kabupaten Ngawi?

b. Bagaimana pengaruh Strategi Pembelajaran Pairs-Checks dan bacaan terhadap hasil belajar siswa Kelas II Sekolah Dasar Negeri Jatigembol 2 Kecamatan Kedunggalar Kabupaten Ngawi?

\section{METODE}

Jenis penelitian yang saya ambil adalah penelitian berupa Penelitian Tindakan kelas (PTK). Jenis penelitian ini mampu menawarkan cara dan prosedur baru untuk memperbaiki dan meningkatkan professionalisme pendidik dalam proses belajar mengajar di kelas dengan melihat kondisi siswa. Penelitian ini juga dapat menjebatani kesenjangan antara teori dan praktik pendidikan.

Dalam penelitian ini Sebagai obyek penelitian adalah semua siswa Kelas II SDN Jatigembol 2 Kecamatan
Kedunggalar Kabupaten Ngawi Tahun Pelajaran 2017/2018 sebanyak 35 siswa.

Sedangkan yang menjadi subjek penelitian ini adalah guru Kelas II SDN Jatigembol 2 Kecamatan Kedunggalar Kabupaten Ngawi Tahun Pelajaran 2017/2018.

Teknik pengumpulan data yang digunakan dalam penelitian ini adalah observasi, angket dan tes.Teknik mengumpulkan data tersebut digunakan untuk memperoleh data sebagai bahan penyusunan penenlitian ini.

Wina Sanjaya (2009) menyatakan bahwa observasi merupakan teknik mengumpulkan data dengan cara mengamati setiap kejadian yang sedang berlangsung dan mencatatnya dengan alat observasi tentang hal-hal yang akan diamati atau diteliti.

Tes dilaksanakan setiap akhir siklus berupa tes formatif yang berguna untuk mengetahui hasil belajar siswa.

\section{HASIL DAN PEMBAHASAN Deskripsi Hasil Penelitian}

Penelitian ini dilaksanakan dalam dua siklus, masing-masing siklus terdiri dari empat tahap yaitu tahap perencanaan (planning), tahap pelaksanaan (acting), tahap pengamatan (observing), dan tahap refleksi (reflecting).

\section{Siklus 1}

\section{Tahap Perencanaan (Planning)}

Perencanaan tindakan meliputi kegiatan menyusun rencana pembelajaran (RP) atau skenario pembelajaran melalui pendekatan Strategi Pembelajaran PairsChecks. Sebagai pendamping guru menggunakan lembar kegiatan siswa (LKS) yang menekankan pada aktivitas membaca, menganalisis, menyimpulkan, dan mengkomunikasikannya. Membuat lembar 
observasi untuk memantau kegiatan pembelajaran, membuat evaluasi untuk mengetahui keberhasilan belajar siswa.

Tahap Pelaksanaan Tindakan (Acting)

Pada pelaksanaan tindakan ini, guru mensosialisasikan pembelajaran tematik Tema Peristiwa melalui pendekatan Strategi Pembelajaran Pairs-Checks sebagaimana tergambarkan pada rencana pembelajaran (RP). Saat berlangsungnya kegiatan belajar mengajar, guru berkeliling membimbing, mengawasi, dan langsung menilai proses pembelajaran terhadap siswa, setelah selesai, guru memberikan penjelasan (klarifikasi) bila terjadi kesalahan konsep dan memberikan kesimpulan, pada akhir pertemuan diadakan evaluasi.

\section{Tahap Pengamatan (Observing)}

Selama berlangsungnya kegiatan belajar mengajar, observasi dilaksanakan dengan menggunakan instrumen yang meliputi : aktivitas siswa dan hasil evaluasi akhir siklus dalam mengelola pembelajaran. Adapun hasil observasi selengkapnya disajikan sebagai berikut :

Tabel Frekuensi Pencapaian Kriteria Aktivitas Belajar Siswa Siklus I

\begin{tabular}{|c|c|c|c|}
\hline \multirow[b]{2}{*}{ Nilai } & \multicolumn{2}{|c|}{ Frekuensi } & \multirow[b]{2}{*}{ Indikator } \\
\hline & $\begin{array}{l}\text { Dari } \\
\text { Guru }\end{array}$ & $\begin{array}{c}\text { Dari } \\
\text { Orangtua }\end{array}$ & \\
\hline B & 35 & 9 & Baik \\
\hline $\mathrm{C}$ & 0 & 18 & Cukup \\
\hline $\mathrm{K}$ & 0 & 8 & Kurang \\
\hline Jumlah & 35 & 35 & \\
\hline
\end{tabular}

Dari tabel dapat diketahui frekuensi latihan yang diberikan oleh guru kepada tiap anak baik, sedangkan frekuensi yang diberikan orang tua beragam, yaitu baik ada 9 anak, cukup ada 18 anak dan kurang ada 8 anak.

Ketuntasan belajar siswa dapat diketahui dengan melakukan tes diakhiri kegiatan pembelajaran.
Tabel Hasil dari ketuntasan belajar pada siklus I

\begin{tabular}{|l|c|c|c|}
\hline $\begin{array}{c}\text { SK } \\
\mathrm{M}\end{array}$ & $\begin{array}{c}\text { Frekuens } \\
\mathrm{i}\end{array}$ & $\begin{array}{c}\text { Presentas } \\
\mathrm{i}(\%)\end{array}$ & $\begin{array}{c}\text { Keteranga } \\
\mathrm{n}\end{array}$ \\
\hline$\geq 70$ & 22 & 63 & Tuntas \\
$<70$ & 13 & 37 & Belum \\
& & Tuntas \\
\hline
\end{tabular}

Dari hasil evaluasi Siklus I nilai yang diperoleh belum memuaskan, nilai rata-rata kelas 72,57 dengan nilai terendah 50 dan nilai tertinggi 85 . Jumlah siswa yang tuntas 22 dan masih ada 13 siswa yang belum tuntas.

\section{Tahap Refleksi (Reflecting)}

Berdasarkan hasil observasi pada siklus 1, diperoleh hasil temuan sebagai berikut:

1) Terdapatnya 35 anak yang mendapat perhatian berupa latihan dari guru dan terdapat 9 anak mendapat latihan yang diberikan orang tua, 18 anak yang cukup mendapat perhatian dari orang tua, 8 anak yang kurang mendapat latihan dari orang tua untuk Strategi Pembelajaran PairsChecks.

2) Terdapat terdapat 35 anak yang catatan dari guru lengkap.

3) Terdapat 23 anak yang buku latihan soalnya lengkap dan 12 anak buku latihan soalnya kurang lengkap

4) Anak belum terbiasa belajar dengan metode Strategi Pembelajaran Pairs-Checks dan kurang senang membaca.

\section{Siklus 2}

Tahap Perencanaan (Planning)

Beberapa hal yang direncanakan guru untuk menyelesaikan permasalahan pada 
siklus pertama adalah (a) guru berusaha berkomunikasi dengan orang tua melalui buku penghubung untuk lebih aktif memperhatikan anaknya untuk memberikan latihan- di rumah, (b) guru berusaha memberikan pemahaman kepada siswa tentang pentingnya membuat catatancatatan selama mendapatkan penjelasan dari guru, (c) guru berusaha berkomunikasi dengan orang tua siswa melalui buku penghubung supaya siswa dapat memiliki buku latihan soal yang lengkap, (d) guru berusaha membiasakan anak untuk belajar dengan metode dan guru memotivasi untuk membiasakan anak supaya gemar membaca buku.

\section{Tahap Pelaksanaan Tindakan (Acting)}

Guru mengawali kegiatan pembelajaran dengan memberi apersepsi berupa pertanyaan kepada siswa. Kemudian guru menyampaikan tujuan pembelajaran, dilanjutkan dengan meminta siswa duduk dalam kelompok yang terdiri dari 4 atau 5 anak. Guru membagi LKS dan meminta siswa untuk secara bersambung membaca bacaan yang ada pada LKS. Selanjutnya guru meminta siswa untuk mengerjakan latihan soal yang ada di LKS pada buku siswa sambil mengingatkan kepada siswa tentang pentingnya gemar membaca. Waktu yang digunakan untuk mengerjakan LKS kurang lebih 20 menit. Kemudian guru meminta wakil kelompok mengerjakan hasil kerja kelompoknya di papan tulis, dilanjutkan dengan tanya jawab. Setelah selesai guru membantu siswa melakukan refleski. Diakhir pembelajaran guru memberikan kuis.

\section{Tahap Pengamatan (Observing)}

Selama berlangsungnya kegiatan belajar mengajar pada Siklus II, observasi dilaksanakan dengan menggunakan instrumen yang meliputi: aktivitas siswa dan hasil evaluasi akhir dalam mengelola pembelajaran. Hasil observasi yang telah dilakukan pada siklus II sebagai berikut:

Tabel Frekuensi Pencapaian Kriteria Aktivitas Belajar Siswa Siklus II

\begin{tabular}{|c|c|c|c|}
\hline \multirow{2}{*}{ Nilai } & \multicolumn{2}{|c|}{ Frekuensi } & \multirow{2}{*}{ Indikator } \\
\cline { 2 - 3 } & $\begin{array}{c}\text { Dari } \\
\text { Guru }\end{array}$ & $\begin{array}{c}\text { Dari } \\
\text { Orangtua }\end{array}$ & \\
\hline B & 35 & 30 & Baik \\
C & 0 & 5 & Cukup \\
K & 0 & 0 & Kurang \\
& & & \\
\hline Jumlah & 35 & 35 & \\
\hline
\end{tabular}

Diketahui frekuensi latihan yang diberikan oleh guru kepada tiap anak baik, sedangkan frekuensi yang diberikan orang tua beragam tetapi ada peningkatan yang jauh lebih baik dari siklus I, yaitu baik ada 30 anak, cukup ada 5 anak.

Ketuntasan belajar siswa dapat diketahui dengan melakukan tes diakhir kegiatan pembelajaran.

Tabel Hasil dari ketuntasan belajar pada siklus II

\begin{tabular}{|l|l|l|l|}
\hline $\begin{array}{c}\text { SK } \\
\mathrm{M}\end{array}$ & $\begin{array}{c}\text { Frekuens } \\
\mathrm{i}\end{array}$ & $\begin{array}{c}\text { Presentas } \\
\mathrm{i}(\%)\end{array}$ & $\begin{array}{c}\text { Keteranga } \\
\mathrm{n}\end{array}$ \\
\hline$\geq 70$ & 31 & 89 & Tuntas \\
$<70$ & 4 & 11 & $\begin{array}{l}\text { Belum } \\
\text { tuntas }\end{array}$ \\
& \multicolumn{4}{|c|}{} \\
\hline
\end{tabular}

Dari hasil evaluasi Siklus II nilai yang diperoleh cukup memuaskan, nilai rata-rata kelas 85,71 dengan nilai terendah 70 dan nilai tertinggi 90. Semua siswa tuntas dalam proses pembelajaran.

\section{Tahap Refleksi (reflecting)}

Berdasarkan hasil observasi pada siklus II, diperoleh hasil temuan sebagai berikut: 
1) Hanya terdapat 5 anak yang cukup mendapat perhatian dari orang tua untuk Strategi Pembelajaran Pairs-Checks.

2) Hanya terdapat 35 anak yang catatan dari guru lengkap.

3) Terdapat 31 anak yang buku latihan soalnya lengkap.

4) Anak mulai terbiasa belajar dengan metode Strategi Pembelajaran Pairs-Checks dan lebih senang membaca.

5) Nilai rata-rata kelas 85,71 dan semua siswa tuntas dalam proses pembelajaran.

Karena berdasarkan refleksi pada Siklus II sudah menunjukkan hasil yang cukup memuaskan maka penelitian ini diakhiri pada siklus II.

\section{PEMBAHASAN}

Berdasarkan paparan data dan temuan penelitian dapat diketahui gambaran umum tentang pengaruh, dan bahan bacaan terhadap hasil pembelajaran tematik siswa Kelas II.

1. Hambatan Pembelajaran Tematik

Hambatan pembelajaran tematik yang dialami oleh siswa Kelas II disebabkan oleh faktor internal yang berasal dari dalam diri siswa dan faktor ekternal yang berasal dari luar diri siswa.

Hambatan belajar siswa Kelas II dalam pembelajaran tematikyang disebabkan oleh faktor intern atau yang berasal dari dalam siswa sendiri, antara lain :

a. Selalu cemas, kurang mampu mengendalikan kecemasannya;

b. Kurang percaya diri dan kurang mampu mengadakan penyesuan diri;

c. Kurang mampu mengikuti penjelasan guru,

Hambatan belajar siswa Kelas II dalam pembelajaran tematik yang disebabkan oleh faktor intern atau yang berasal dari dalam siswa sendiri, antara lain : a. Tergantung dari pihak lain (guru atau orang tua/keluarga);

b. Kegiatannya kurang berwawasan pada segi pembelajaran tematik.

2. Pengaruh Terhadap Hasil Belajar Berdasarkan hasil penelitian menunjukkan bahwa yang diberikan kepada siswa Kelas II berpengaruh tertradap hasil pembelajaran tematiksiswa. Semakin tinggi frekuensi yang diberikan oleh guru dan orang tua dalam setiap minggu, maka semakin baik hasil pembelajaran tematik siswa Kelas II. Sebaliknya semakin rendah frekuensi yang diberikan oleh gurui dan orang tua dalam setiap minggunya, maka semakin rendah hasil pembelajaran tematik siswa Kelas II.

3. Pengaruh Bahan Bacaan Terhadap Hasil Belajar

Semakin lengkap koleksi bahan bacaan, maka semakin membantu dalam proses belajar siswa. Koleksi bahan bacaan merupakan salah satu variabel yang menentukan terhadap hasil belajar siswa Kelas II. Siswa Kelas II yang mempunyai koleksi bacaan yang lengkap, maka ia akan memperoleh hasil belajar yang memuaskan. Sebaliknya siswa yang memiliki koleksi bacaan yang kurang lengkap atau tidak lengkap, maka ia akan mencapai hasil belajar yang kurang memuaskan.

Bahan bacaan sangat menentukan keberhasilan siswa dalam Pembelajaran Tematik, karena dengan semakin banyak bahan bacaan akan diperoleh banyak informasi tentang pembelajaran tematik, baik itu melalui latihan soal atau pemecahan masalah yang berhubungan dengan pembelajaran tematik. Bahan bacaan yang dimilki siswa meliputi catatan dari guru, buku paket, buku latihan soal dan majalah anak-anak dan lain-lain yang berhubungan dengan pembelajaran tematik. Berdasarkan hubungan koleksi bahan bacaan dan hasil belajar siswa Kelas II 
terhadap pembelajaran tematik, maka sangat diperlukan penyediaan bahan bacaan oleh sekolah maupun orang tua dalam membantu proses belajar anak dalam upaya meningkatkan hasil belajar.

\section{SIMPULAN}

Berdasarkan rumusan masalah, hasil penelitian tentang meningkatkan hasil pembelajaran tematik terhadap siswa Kelas II Sekolah Dasar Negeri Jatigembol 2 Kecamatan Kedunggalar Kabupaten Ngawi dengan Strategi Pembelajaran PairsChecks, maka dapat ditarik beberapa kesimpulan.

1. Hambatan pembelajaran tematik yang dialami oleh siswa Kelas II Sekolah Dasar Negeri Jatigembol 2 Kecamatan Kedunggalar Kabupaten Ngawi disebabkan oleh faktor internal (dari diri siswa) dan faktor eksternal (dari luar siswa/ lingkungan). Setelah dilakukan program Strategi Pembelajaran Pairs-Checks dan dihubungkan dengan koleksi bahan bacaan yang dimiliki siswa, maka dapat disimpulkan bahwa hambatan belajar siswa Kelas II lebih disebabkan oleh faktor internal. Faktor internal yang dimaksud adalah kelemahan akademis, sikap negatif (malas, kurang percaya diri, kurang bertanggung jawab).

2. Strategi Pembelajaran PairsChecks berpengaruh terhadap hasil belajar siswa Kelas II Sekolah Dasar Negeri Jatigembol 2 Kecamatan Kedunggalar Kabupaten Ngawi. Semakin tinggi frekuensi Strategi Pembelajaran PairsChecks yang diberikan oleh guru dan orang tua, maka semakin kuat kemampuan Strategi Pembelajaran Pairs-Checks dapat dipraktekkan oleh siswa, sehingga akan meningkatkan hasil belajar siswa Kelas II Sekolah Dasar Negeri Jatigembol 2
Kecamatan Kedunggalar Kabupaten Ngawi dalam mata pembelajaran tematik.

\section{SARAN}

Peningkatan hasil belajar siswa merupakan harapan semua pihak, oleh karena itu perlu kerjasama yang baik antara pihak sekolah (guru), orang tua dan siswa untuk saling membantu dalam upaya meningkatkan hasil belajar siswa. Hasil dari Strategi Pembelajaran PairsChecks dalam mewujudkan prestasi siswa sangat dirasakan. Dengan kenyataan ini disarankan kepada guru dan orang tua untuk menerapkan Strategi Pembelajaran Pairs-Checks siswa terhadap pembelajaran tematik di sekolah dasar.

Disarankan agar penerapan Strategi Pembelajaran Pairs-Checks guna melahirkan motif prestasi dan kelangkapan koleksi bahan bacaan yang harus dimilki siswa hendaknya dilakukan pada setiap mata pelajaran. Semoga hasil penelitian ini dapat bermanfaat dalam menerapkan metode pengajaran sesuai dengan fokus penelitian ini, yaitu Strategi Pembelajaran Pairs-Checks terhadap peningkatan hasil belajar siswa.

\section{DAFTAR PUSTAKA}

Ali, Muhammad. (1996). Guru Dalam Proses Belajar Mengajar. Bandung: Sinar Baru Algesindon.

Combs. Arthur. W. (1984). The Profesional Education of Teachers. Allin and Bacon, Inc. Boston.

Dahar, R.W. (1989). Teori-teori Belajar. Jakarta: Erlangga. 
Djamarah, Syaiful Bahri. (2000). Strategi Belajar Mengajar. Jakarta: Rineksa Cipta.

Hadi, Sutrisno. (1981). Metodoiogi Research. Yayasan Penerbitan Fakultas Psikologi Universitas Gajah Mada. Yoyakarta.

Hadi, Sutrisno. (1982). Metodologi Research, Jilid 1. Yogyakarta: YP. Fak. Psikologi UGM.
Hamalik, Oemar. (1994). Metode Pendidikan. Bandung: Citra Aditya Bakti.

Hasibuan. J.J. dan Moerdjiono. (1998). Proses Belajar Mengajar. Bandung: Remaja Rosdakarya.

Kemmis, S. dan Mc. Taggart, R. (1988). The Action Research Planner. Victoria Dearcin University Press. 